\title{
The effect of the precipitation pattern of the dry season on peat fire occurrence in the Mega Rice Project area, Central Kalimantan, Indonesia
}

\author{
Erianto Indra Putra ${ }^{1^{*}}$ and Hiroshi Hayasaka ${ }^{2}$ \\ 'Department of Silviculture, Faculty of Forestry, Bogor Agricultural University, Indonesia \\ ${ }^{2}$ Graduate School of Engineering, Hokkaido University, 060-8628, Japan
}

\begin{abstract}
Indonesia has experienced severe tropical forest fires from a long time ago, mainly in El Niño years. However, previous studies showed that after 1997 forest and peat fires in Indonesia tend to occur every year in the dry season, even in non El Niño years. To clarify this recent pattern of incidence, we studied the fire situation in the Mega Rice Project (MRP) area, Central Kalimantan where large scale development of tropical swamp-forest has been carried out since 1996. To identify the causes of the recent severe peat fires, weather data for Palangkaraya from 1978 to 2007, hotspot data captured by the MODIS satellite, monthly Niño 3.4 sea surface temperature (SST) anomalies, and ground water level (GWL) data were analyzed. The results of the analysis clearly showed a relationship among the precipitation pattern of the dry season, GWL change, Niño 3.4 SST Anomalies, and fire occurrences. A pattern of low precipitation in the dry season decreased GWL and caused a peat fire peak in the middle of August when daily precipitation reached the minimum. These results suggest that large areas of bared peat in the MRP now has a high susceptibility to fire coupled with the precipitation pattern of the dry season.
\end{abstract}

Key words : ground water level, Mega Rice Project, Niño 3.4 SST Anomalies, peat fire, precipitation

\section{INTRODUCTION}

Fires in tropical forest and peat areas in Indonesia are not a new phenomenon. Forest fires have repeatedly burned areas of Indonesian lowland rain forest since about 13,200 BC (Goldammer and Seibert 1989) and these fires are more pronounced in El Niño years. However, previous studies indicated that after 1997 forest and peat fires in Indonesia tend to occur every year in the dry season (Dennis 1999, Adinugroho et al. 2005, Murdiyarso and Aidaningsih 2006, Hayasaka 2007, Ministry of Forestry 2008), even in non El Niño years (Putra et al. 2008). This change in fire incidence in Indonesia may be related to the rapid decrease in forest areas. The total forest area of Indonesia was $1,622,900 \mathrm{~km}^{2}$ in 1950 but had decreased to $939,243 \mathrm{~km}^{2}$ in 2002/2003 (Ministry of Forestry 2008). Thus, forest loss in Indonesia during these 52 years reached $42.1 \%$ of the total original forested area. Based on the 1990 forest cover, the annual deforestation rate in Central Sumatra reached $3.2-5.9 \%$ and $1.0-2.7 \%$ in Southeastern Kalimantan (Frederic et al. 2002).

Fires and the dry season occur together in all Indonesian regions. Our previous study (Putra et al. 2008) showed that more than $90 \%$ of peat fires in Central Kalimantan from 1997 to 2007 occurred in the dry season.
The ground water level (GWL) in peatland areas is lowered under dry weather conditions, and one result is a drying up of peat and organic fuel in the upper layers which create the conditions for fires to be ignited.

Around $30,951 \mathrm{~km}^{2}$ or $20 \%$ of the area of Central Kalimantan is peatland (Hooijer et al. 2006) and most of this remained pristine up to the beginning of the 1990s (Siegert et al. 2001). In 1996, the Indonesian Government initiated the Mega Rice Project (MRP) to develop a million hectares of rice fields in the tropical swamp-forest between the Sebangau and Barito rivers in Central Kalimantan, Indonesia. More than $63 \%\left(9,191 \mathrm{~km}^{2}\right)$ of the total MRP area is peatland (Notohadiprawiro 1998), making this project a giant among the tropical swampforest conversion projects in Indonesia. The MRP ended in 1999 but it has left vast drained peatland areas and has brought with it serious peat fire problems as a result. Peat fires in this area become very active mainly during droughts or the dry season of El Niño years, but a large number of fires were also occurring in the dry season of non El Niño years when the Niño 3.4 SST anomaly had small positive values, as occurred in 2001, 2003, and 2005 (Putra et al. 2008). This evidence clearly shows the importance of clarifying the influence of precipitation in the dry season, as well as the influence of Niño 3.4 SST 
anomalies and GWL on peat fire occurrences in the MRP area.

In this study, the precipitation pattern in the dry season were established by analyzing 30 years of daily weather data measured at Palangkaraya, Central Kalimantan. The relationship among precipitation, Niño 3.4 SST Anomalies, ground water level, and peat fire occurrence in the MRP area were also established.

\section{METHODOLOGY}

This study analyzed daily weather data (precipitation) of Palangkaraya, daily hotspot occurrences in the MRP area, monthly Niño 3.4 sea surface temperature (SST) Anomalies, and daily ground water level changes. The precipitation pattern was analyzed with the 30 years of daily weather data from 1978 to 2007 measured at the Tjilik Riwut Climatology Station, Palangkaraya located at $2.23^{\circ} \mathrm{S}, 113.95^{\circ} \mathrm{E}$. The Tjilik Riwut Climatology Station is a governmental weather station under Indonesian Meteorological, Climatology and Geophysical Agency (BMKG). The lowest precipitation recorder at the station is $0.1 \mathrm{~mm}$.

For the daily precipitation data, there are a small number of days with missing data. Total missing data for precipitation were 50 out of 10,957 total daily precipitation data, or around $0.5 \%$. Daily precipitation missing data are scattered in various years: 1987 (3 days), 1989 (3), 1990 (6), 1991 (2), 1992 (4), 2000 (3), 2001 (2), 2005 (5), 2006 (1), and 2007 (17), and scattered on different days. Most of these data were for different dates and only two missing data occurred on the same date. Since the daily values were taking into consideration, these few missing data have only a small affect on the total data and any effect of the missing data can be disregarded.

Analysis of daily hotspots used the data captured by the MODIS satellite (NASA/University of Maryland 2002) from 2001 to 2007 . The MODIS satellite has a daily temporal resolution and 1000-m spatial resolution. The system provides special algorithms to detect the hotspots or fire occurrences in the area and send the results to the end-user. Therefore we used the number of hotspots detected by MODIS satellite to show the number of fires in the study area.

Here we use the SST Anomaly for the Nino 3.4 region $\left(120^{\circ}-150^{\circ} \mathrm{W}\right.$ and $\left.5^{\circ} \mathrm{N}-5^{\circ} \mathrm{S}\right)$. The Niño $3.4 \mathrm{SST}$ anomaly data derived from the NOAA-National Weather Service used to establish the relationship among SST anomalies, precipitation, and peat fire occurrences. The
SST anomalies could be defined simply as how much the temperatures departs from its normal condition. According to Trenberth (1997), an El Niño event occurs when SST anomalies in the Niño 3.4 region exceed $+0.4^{\circ} \mathrm{C}$ for 6 months or longer and inversely, a La Niña event will occur when SST Anomalies are below $-0.4^{\circ} \mathrm{C}$. Using this threshold, we defined 1982, 1987, 1991, 1997/1998, 2002 and 2006 as the El Niño years. The El Niño events affect the interannual variation of climate in Australia, Indonesia, and the rest of Southeast Asia. Together with the Southern Oscillation (SO), sea surface temperature (SST) anomalies cause drought in years coinciding with strong El Niño events (Murdiyarso and Aidiningsih 2006).

To evaluate the precipitation and its influence on the peat fire occurrences, two indicators are introduced here, rainless days and rainy days. Rainless days are defined as days with $1.5 \mathrm{~mm}$ or less precipitation and rainy days are days with more than $10 \mathrm{~mm}$ of precipitation. A daily precipitation of $1.5 \mathrm{~mm}$ is used as the threshold to determine the rainless days (Flannigan and Harrington 1988). Rainless days, rainy days, the total number of rainless days (TNR), and the maximum number of consecutive rainless days (MNR) were calculated using daily precipitation data to assess the severity of the dry season in a year. The TNR and MNR show variability and the timing of precipitation (Holden et al. 2007), thus a combination of TNR and MNR in the dry season could determine the severity of a dry season.

Dry and wet seasons represent the condition when dry or wet months occur in several consecutive months. A dry month is categorized when monthly precipitation is below $100 \mathrm{~mm} / \mathrm{month}$ and a wet month when precipitation is more than $200 \mathrm{~mm} /$ month (MacKinnon et al. 1996). Usually the dry season in Central Kalimantan occurs from July to September.

In this paper we also introduce dry and wet periods to explain the weather conditions in Palangkaraya instead of dry and wet seasons. The dry and wet periods are defined based on the observational mean of daily precipitation from $1978-2007$. If the period had the daily precipitation below the mean value, this period is considered as a dry period.

Nine-year daily ground water level measurement done by Takahashi et al. (2007) is averaged by using 5-day running averages to develop the daily GWL observational means. The measurement point located at $2.32^{\circ} \mathrm{S}, 113.90^{\circ} \mathrm{E}$ on the upper catchment of River Sebangau about $800 \mathrm{~m}$ from the forest edge and $2 \mathrm{~km}$ from the river along the logging railway at the right bank of the 


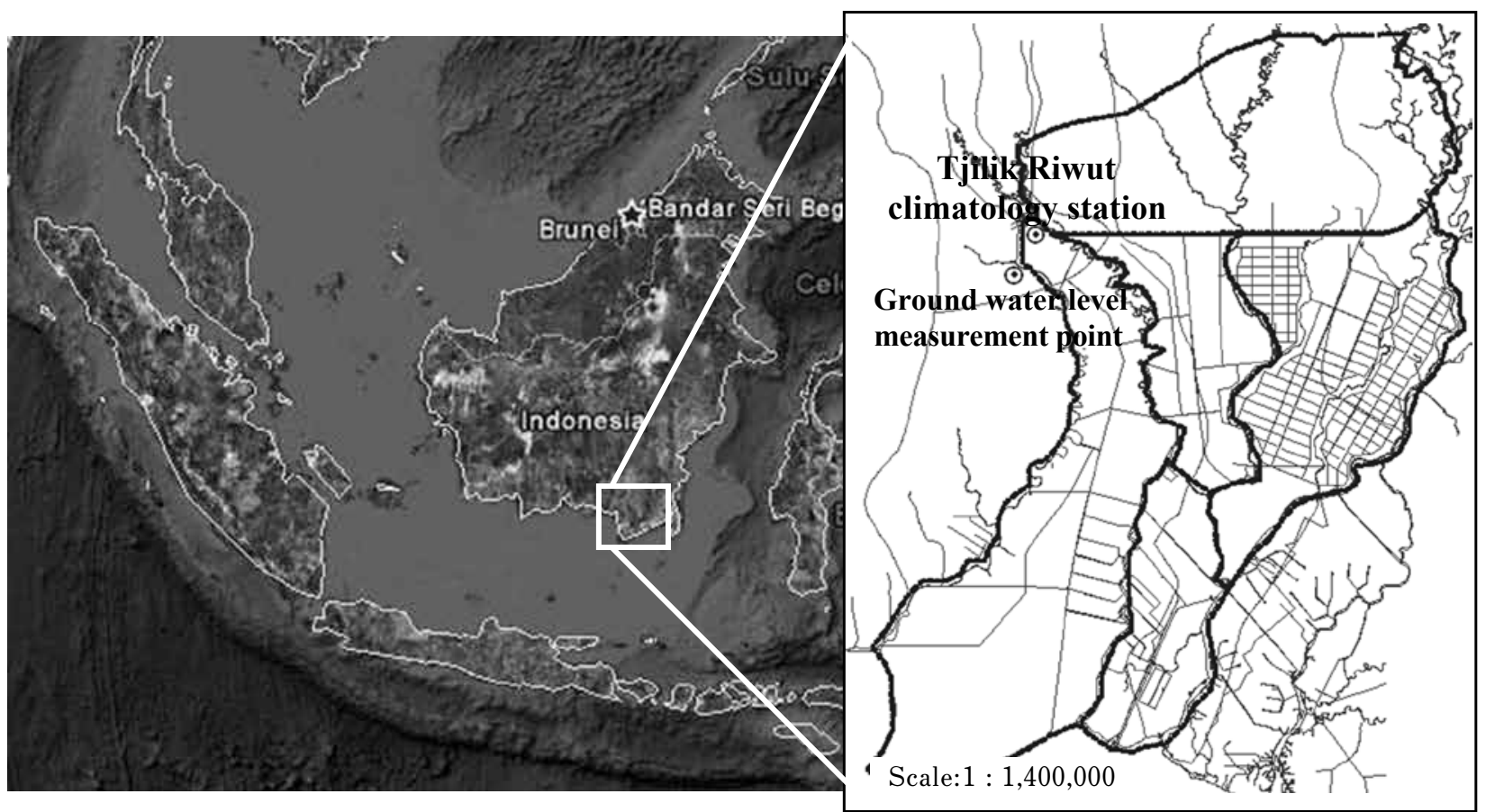

Fig. 1. Study area and location of Tjilik Riwut Climatology Station and ground water level measurement point.

Sebangau River. The altitude of the measurement point was approximately $30 \mathrm{~m}$ above sea level. The depth of peat near the measurement point is approximately 3 meters. The ground water level was measured with a pressure sensor and data logger (1993-2000:Druck Ltd, PDCR830 and Kona System, Kadec-Mizu,2000-2008:STS $\mathrm{DL} / \mathrm{N}$ ). The interval of measurements is one hour and the water level represented the depth from the ground surface to ground water surface.

Precipitation and hotspot data were processed by five-day running averages to obtain the smoothed daily and seasonal observational means. The study area and the measurement point for precipitation and ground water level are shown in Fig. 1.

\section{RESULTS AND DISCUSSION}

Precipitation pattern, SST Anomalies, and peat fire occurrence

Like other tropical regions, Central Kalimantan experiences two seasons namely a dry and a wet season. Previous studies (Putra et al. 2008, Aldrian and Susanto 2003, Usup et al. 2004, MacKinnon et al. 1997) have defined dry and wet seasons in Central Kalimantan by using the monthly rainfall variation. But this monthly precipitation is not sufficient to understand the fires that occur almost every day even in June or before the dry season. Therefore we examined the precipitation variability to investigate the influence of precipitation variability on the fire activity in the MRP area by analyzing the 30 -years of daily precipitation data from 1978 to 2007.

The analysis clearly shows a U-shaped precipitation pattern in Palangkaraya with a high plateau from December to March and a trough reaching minimum in the middle of August (Fig. 2), clearly shows the actual wet and dry periods in Palangkaraya. This pattern is one of three typical precipitation patterns in Indonesia (Aldrian and Susanto 2003). A daily mean precipitation $(7.8 \mathrm{~mm})$ is used here to differentiate the dry and wet periods in Palangkaraya.

The wet period lasts for about seven months and it is two months longer than the dry periods. Thus, the length of the dry periods is about five months from the start of June (DN 152) to the end of October (DN 301). This study defines June to October as the dry periods in Palangkaraya.

The precipitation pattern in Fig. 2 clearly shows the large difference in precipitation between the wet and dry periods in Palangkaraya. There is a more than two times difference between the mean daily precipitation values in the dry periods $(4.7 \mathrm{~mm})$ and wet periods $(10.0 \mathrm{~mm})$, and the total precipitation in the dry periods $(698.9 \mathrm{~mm})$ is 


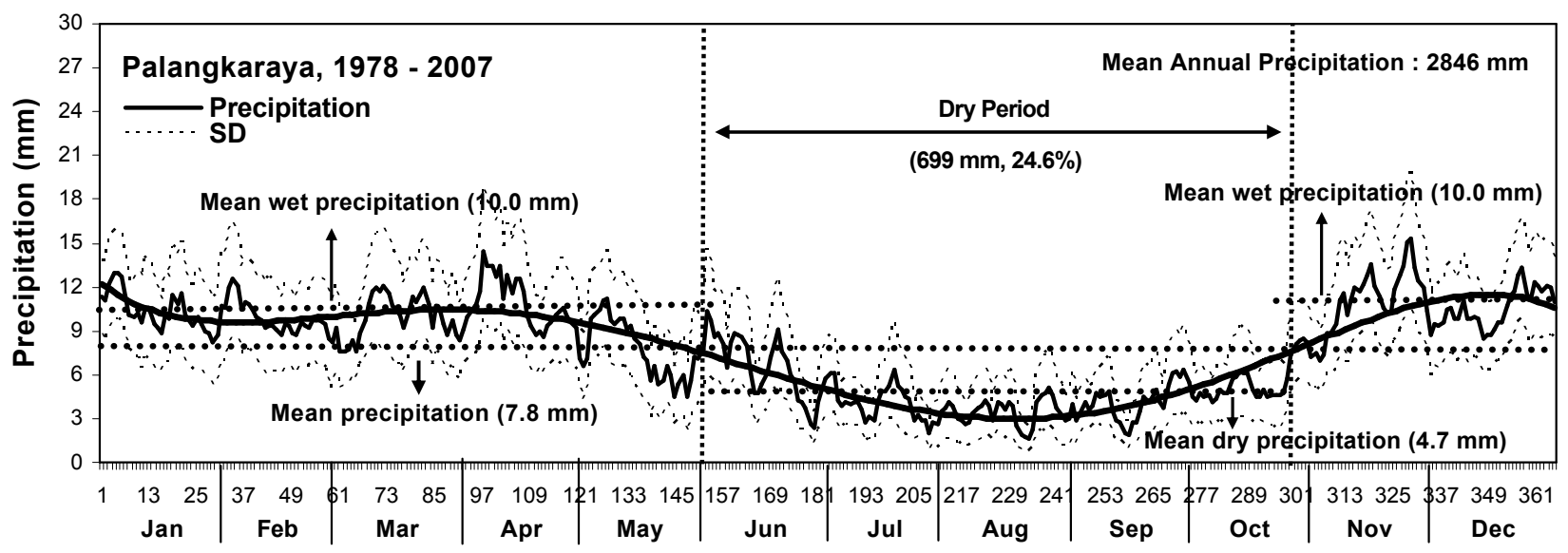

Day Number

Fig. 2. The annual precipitation cycle in Palangkaraya. Smoothed-thick curve represents the daily precipitation observational mean.

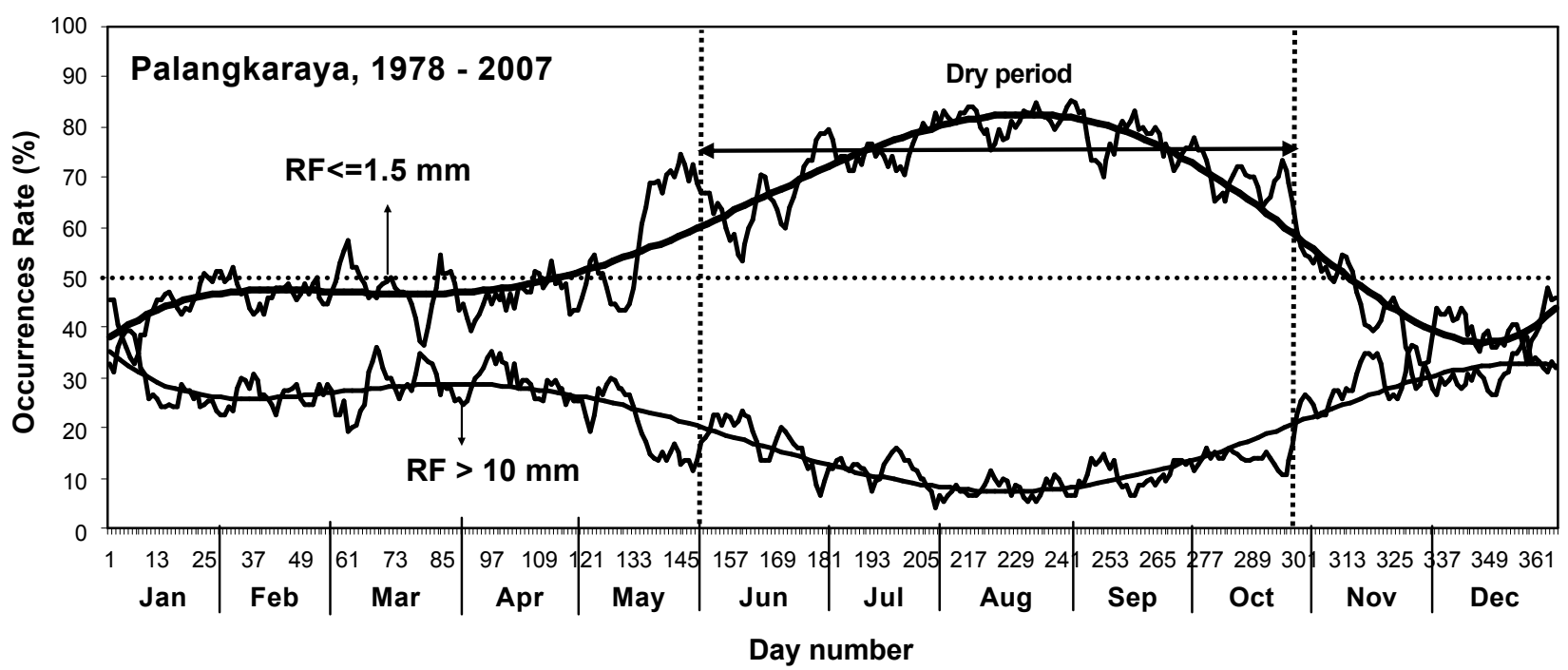

Fig. 3. The 5 day moving average occurrences rates (\%) of rainless days $(\leq 1.5 \mathrm{~mm})$ and rainy days $(>10 \mathrm{~mm})$ in Palangkaraya, 1978 - 2007. Smoothed-thick curve represents the occurrences rate of observed means of daily rainfall of more than $10 \mathrm{~mm}$ (bottom curve) and same or less than $1.5 \mathrm{~mm}$ (upper curve).

only $1 / 3$ of that in the wet periods, this pattern clearly describes the overall dry climate conditions in Palangkaraya during the dry period.

Low daily precipitation, less than the mean dry precipitation $(4.7 \mathrm{~mm})$, occurred between July and September and the lowest daily precipitation of less than $3 \mathrm{~mm}$ is in the middle of August. Low precipitation brings a drier climate and increases the dryness of the peat in the MRP area.

Fig. 3 shows the daily occurrence rates of rainless and rainy days in Palangkaraya based on the 30-year daily precipitation analysis. The rates of occurrence of rainy days form a U-curve shaped pattern. The inverted U-curve shape is for the rate of occurrence of rainless days. The rate of occurrence of rainless days is higher than the number of rainy days in a year.

Occurrence rates of rainless days in the wet period are between 38 and $60 \%$ and increases to more than $60 \%$ in the dry period. The occurrence rates of rainy days are between 20 and $36 \%$ in the wet period and less than $15 \%$ in the dry period. In the peak of the dry period, the middle of August, there are not only high occurrence rates (more than $80 \%)$ of rainless days but also low occurrence rates (less than 10\%) of rainy days. Under these occurrence rates, dry weather conditions are created and conducive conditions of ignition of peat are created; stimulating the high fire activity in the area in this period.

Almost all of the past positive Niño 3.4 SST Anomalies or El Niño events brought droughts to Indonesia. The total amount of precipitation during the 


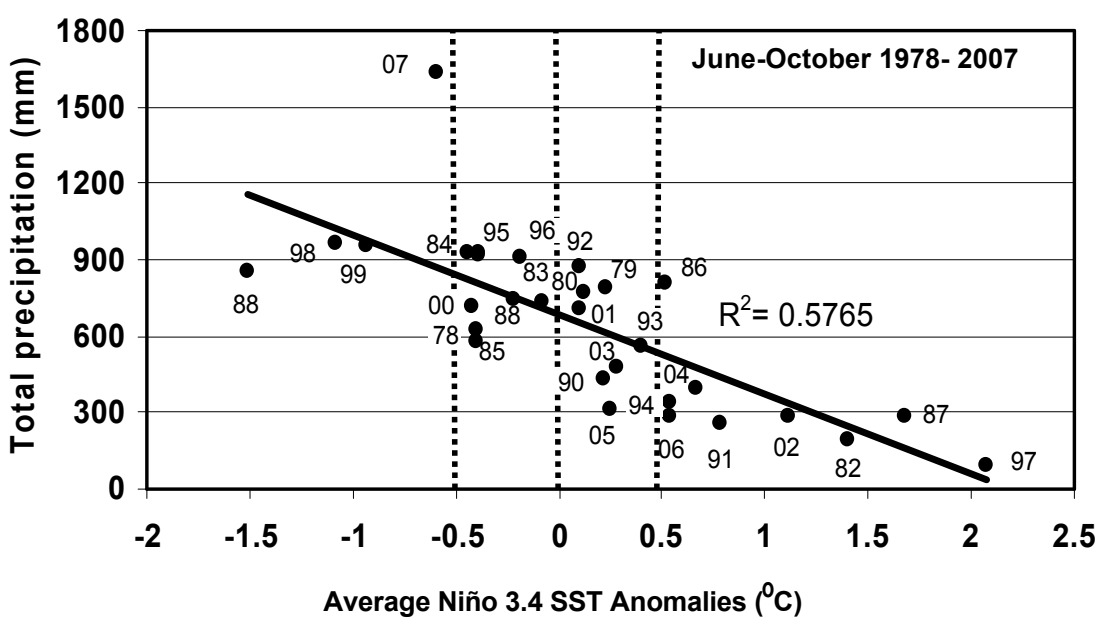

Fig. 4. Correlation between Nino 3.4 SST Anomalies and total precipitation June to October, $1978-2006$.

dry period in Palangkaraya is estimated at around 698.9 $\mathrm{mm}$ or $24.6 \%$ of mean annual precipitation $(2845.7 \mathrm{~mm})$. However the amount of precipitation in the dry period of El Niño years may be below $15 \%$ of the mean annual precipitation $(2845.7 \mathrm{~mm})$, such as in $1982(240.8 \mathrm{~mm}$, 8.46\%), 1987 (347.5 mm, 12.21\%), 1991 (292.8 mm, 10.29\%), 1997 (117.0 mm, 4.11\%), 2002 (308.1 mm, $10.83 \%)$, and in 2006 (294.5 mm, 10.35\%). These numbers suggest that severe droughts occurred during the dry period of El Niño years, with resulting severe fire occurrences. The number of hotspots or fires detected in Central Kalimantan are 26,757 in 1997; 19,470 in 2002; and 41,102 in 2006 (Putra and Hayasaka 2007).

There is a negative correlation between Niño 3.4 SST Anomalies and precipitation in Palangkaraya during the dry period (Fig. 4). Previously, a strong correlation between SST anomalies and the precipitation variability were reported for some regions in Indonesia (Aldrian and Susanto 2003). The Niño 3.4 SST Anomalies of more than $+0.5^{\circ} \mathrm{C}$ bring less than $500 \mathrm{~mm}$ precipitation in the dry period such as in $1991\left(292.8 \mathrm{~mm},+0.8^{\circ} \mathrm{C}\right), 2004$ $\left(451.8 \mathrm{~mm},+0.7^{\circ} \mathrm{C}\right)$, and $2006(294.5$ $\left.\mathrm{mm},+0.5^{\circ} \mathrm{C}\right)$. Less than $350 \mathrm{~mm}$ precipitation occurred in the dry period when the Niño 3.4 SST anomalies average was above $+1^{\circ} \mathrm{C}$ as in $1982\left(240.8 \mathrm{~mm},+1.4^{\circ} \mathrm{C}\right), 1987$ $\left(347.5 \mathrm{~mm},+1.7^{\circ} \mathrm{C}\right)$, and $2002(308.1$ $\left.\mathrm{mm},+1.1^{\circ} \mathrm{C}\right)$. There was only 117.0 $\mathrm{mm}$ of precipitation during the dry period of 1997 when the Niño 3.4 SST anomaly averaged $2.1^{\circ} \mathrm{C}$.

Low Niño 3.4 SST Anomalies smaller than $-0.5^{\circ} \mathrm{C}$ brings large amounts of precipitation in the dry period. The amount of precipitation in the dry period exceeded $850 \mathrm{~mm}$ in 1988, 1998, 1999, and 2007 when the Niño 3.4 SST Anomalies in the dry period were below $-0.5^{\circ} \mathrm{C}$. However, below mean value precipitation also occurred in several neutral or non El Niño years such as in 1990, 2003, and 2005, when there were low positive Niño 3.4 SST Anomalies, between $+0.1^{\circ} \mathrm{C}$ and $+0.5^{\circ} \mathrm{C}$, in the dry season.

This study used the total number of rainless days (TNR) and the maximum number of consecutive rainless days (MNR) in the dry season to assess fire risks in the MRP area based on the precipitation variability. Considerable variation in fire risks from year to year in MRP has been shown to be closely related to the rainfall and length of dry season (Wösten et al. 2008).

The longest TNR (144 days) and MNR (98 days) occurred in the dry period between June and October of 1997 (Fig. 5) when the highest Niño 3.4 SST Anomalies also occurred $\left(+2.6^{\circ} \mathrm{C}\right)$, and made 1997 experience the

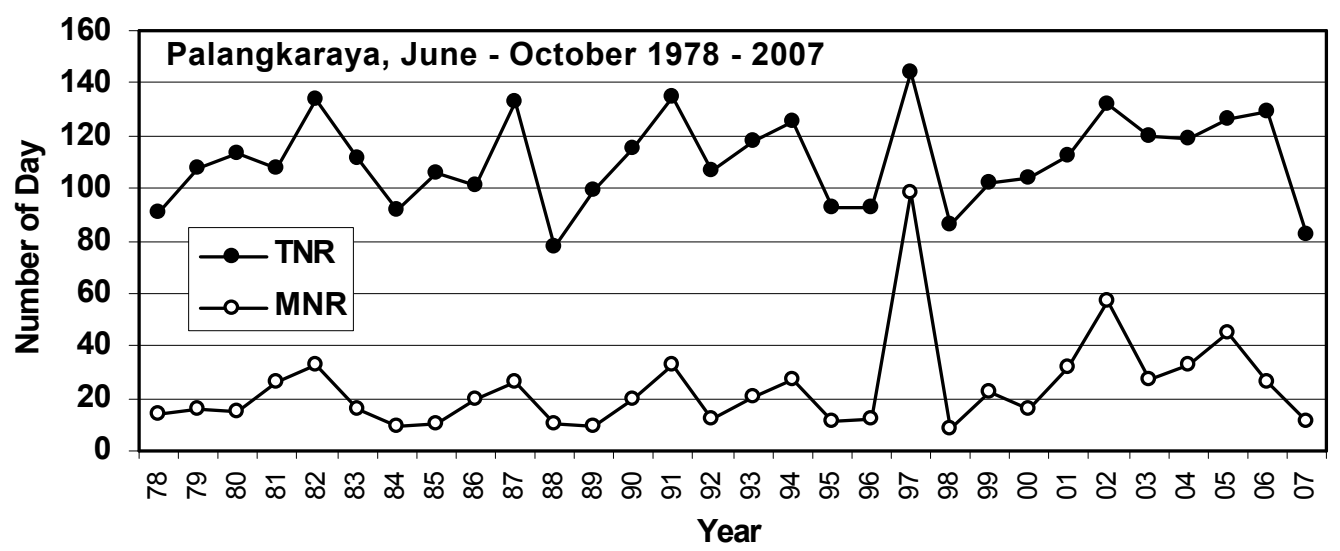

Fig. 5. Total number of rainless days (TNR; black dots) and maximum number of consecutive rainless days (MNR; white dots) from June to October, 1978 - 2007. 
Table 1. Average Nino 3.4 SST Anomalies (Ave SSTA, oC), Maximum Nino 3.4 SST Anomalies (Max SSTA, oC), total number of rainless days (TNR), maximum consecutive rainless days (MNR), number of hotspot (HS), total precipitation (Tot Prcp, $\mathrm{mm}$ ) and minimum groundwater level (Min GWL, cm) during dry period (June-October), 1997 - 2007.

\begin{tabular}{lrrrrrrrrrrrrr}
\hline & 1997 & 1998 & 1999 & 2000 & 2001 & 2002 & 2003 & 2004 & 2005 & 2006 & 2007 & SD & Average \\
\hline Ave. SSTA & $\mathbf{2 . 1 *}$ & $-1.1^{* *}$ & $-0.9^{* *}$ & -0.4 & 0.1 & $\mathbf{1 . 1}$ & 0.3 & 0.7 & 0.3 & $\mathbf{0 . 5}$ & -0.6 & 0.93 & 0.2 \\
Max. SSTA & $\mathbf{2 . 6 4 *}$ & $-0.78^{* *}$ & $-0.73^{* *}$ & -0.25 & 0.24 & $\mathbf{1 . 4 6}$ & 0.6 & 0.83 & 0.56 & $\mathbf{0 . 8 8}$ & 0.06 & 0.99 & 0.5 \\
TNR & $\mathbf{1 4 4 *}$ & $86^{* *}$ & 102 & 104 & 112 & $\mathbf{1 3 2}$ & 120 & 119 & 126 & $\mathbf{1 2 9}$ & $82^{\wedge}$ & 19.26 & 114.2 \\
MNR & $\mathbf{9 8 *}$ & 8 & 22 & 16 & 32 & $\mathbf{5 7}$ & 27 & 33 & 45 & $\mathbf{2 6}$ & 11 & 25.57 & 34.1 \\
HS & $\mathbf{N} / \boldsymbol{A}$ & $\mathrm{N} / \mathrm{A}$ & $\mathrm{N} / \mathrm{A}$ & $\mathrm{N} / \mathrm{A}$ & 1513 & $\mathbf{2 0 5 6}$ & 2153 & 4618 & 2648 & $\mathbf{7 0 1 7}$ & $147^{* *}$ & 2263.28 & 2878.9 \\
Tot Prcp & $\mathbf{9 5 *}$ & 967 & 954.3 & 720.1 & 702.6 & $\mathbf{2 8 6 . 1}$ & 476.5 & 393 & 308.4 & $\mathbf{2 8 7} 1631.6^{* *}$ & 440.4 & $\mathbf{6 2 0 . 2}$ \\
Min GWL & $\mathbf{- 9 3 . 8}$ & $-14.4^{*}$ & $-31.4^{*}$ & -41.6 & -56.9 & $\mathbf{- 1 1 8 . 5 * *}$ & -76.8 & -81.7 & -67.2 & $\mathbf{- 6 2 . 8}$ & N/A & 30.59 & -64.5 \\
\hline
\end{tabular}

Note :

El Nino years is indicated in bold-italic.

* : indicate that the value is more than 1 SD from average

** : indicate that the value is less than $1 \mathrm{SD}$ from average

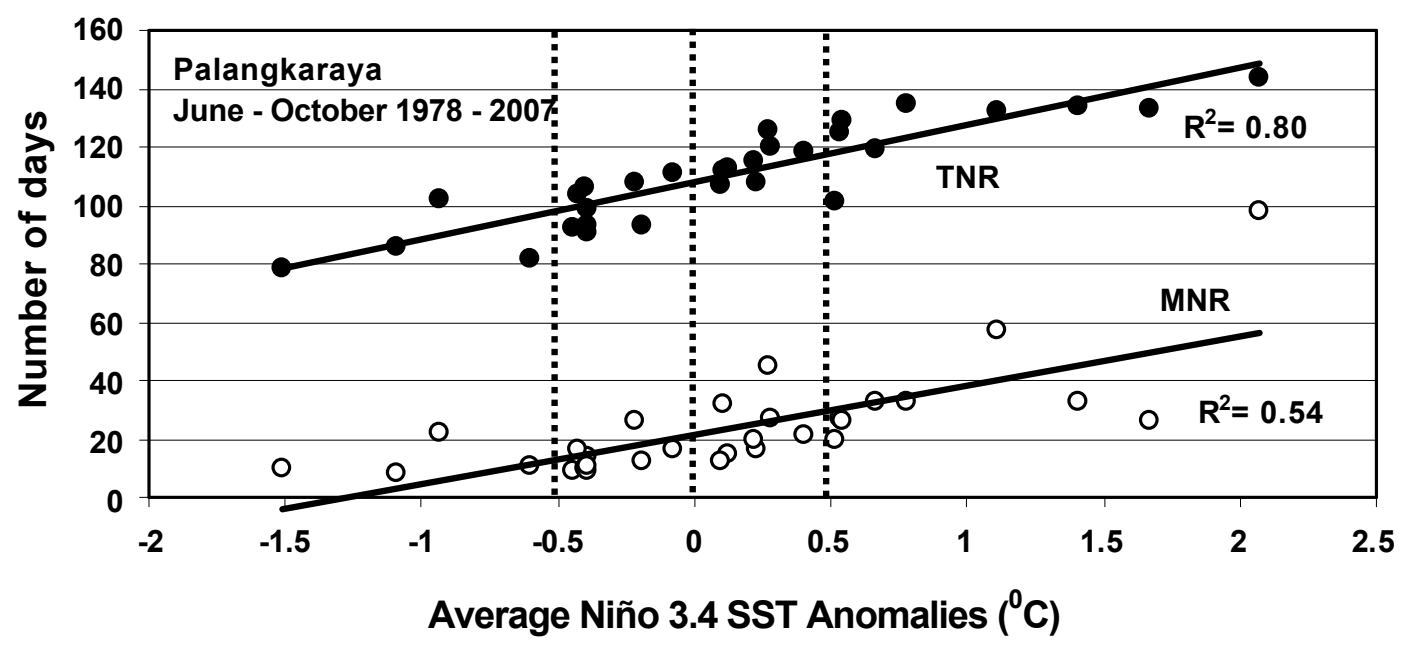

Fig. 6. Relationship between Nino 3.4 SST Anomalies, total number of rainless days (TNR; black dots), and maximum number of consecutive rainless days (MNR; white dots) from June to October, 1978 - 2007.

most severe dry season in the last 10 years (Table 1). This high positive Niño 3.4 SST Anomalies of more than $+0.5^{\circ} \mathrm{C}$ in 1997 lasted longer, from June 1997 until March 1998, and made 1997/1998 the longest El Niño event in the decades.

Another high TNR and MNR occurred in the El Niño year of 2002, which brought another long dry period in Palangkaraya. Further, the TNR in the dry periods of 2000 to 2006 all exceeded 100, indicating that; recently, a severely dry period has become an annual occurrence in Palangkaraya. There is an exception in 2007 which suffered from an exceptionally large rainfall all of the year due to a La Niña event. Thus, this study clearly showed a positive correlation between Niño 3.4 SST Anomalies and both of TNR and MNR (Fig. 6); indicating that the recent severe dry conditions in Palangkaraya are closely related with positive Niño 3.4 SST Anomaly occurrences.
Hotspots or fires in the MRP area numbered 7017, 4618, and 2052 in the dry periods of the El Niño years 2006, 2004, and 2002, respectively (Fig. 7). The large number of hotspots showed that peat fires in the MRP area are more common in El Niño years. Murdiyarso and Adiningsih (2006) showed the role of the El Niño Southern Oscillation (ENSO) in providing dry weather inducing biomass burning and widespread fires. However, there were more than 1,500 fires in the dry period (June to October) of the non El Niño years of 2001, 2003, 2004, and 2005 when the Niño 3.4 SST Anomalies were between $+0.1^{\circ} \mathrm{C}$ and $0.3^{\circ} \mathrm{C}$, indicating that recently a large number of fires is strongly correlated with positive Niño 3.4 SST Anomalies, even when the values are low positive ones.

The peat fire occurrence graph for the MRP area (Fig. 8) clearly shows that intermittent fires occur in the wet season but that fires are much more intense in the 


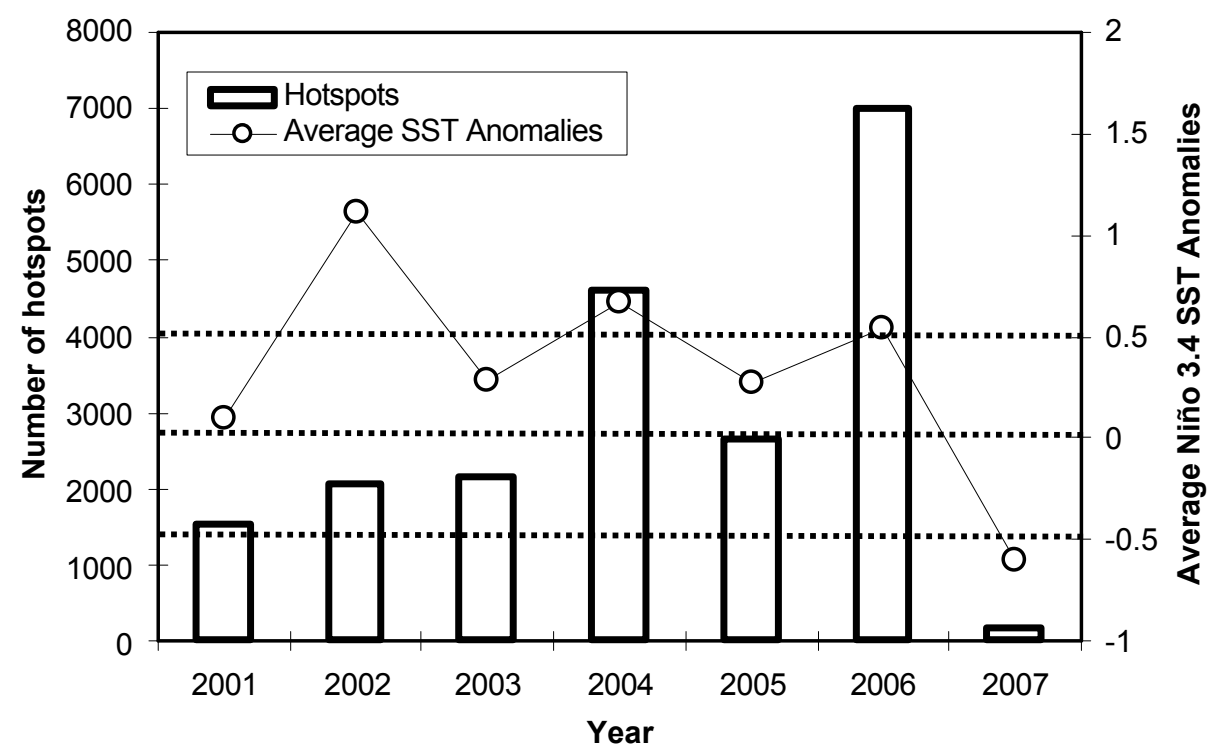

Fig. 7. Number of hotspots and Nino 3.4 SST Anomalies in dry periods, $2001-2007$.

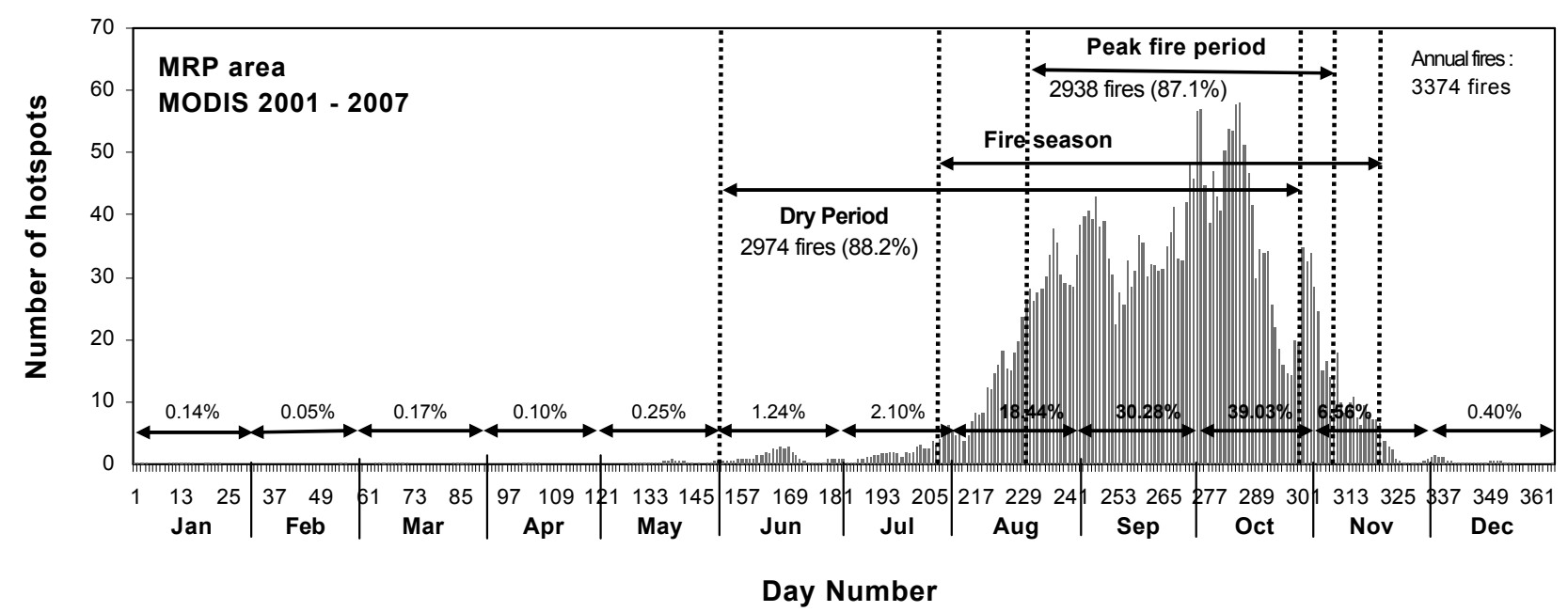

Fig. 8. Daily hotspot occurrences, $2001-2007$.

dry period. The number of fires increased progressively in the dry period as the dry period progressed. Fires in the starting month of the dry period (June) contributed only $1.24 \%$ of the total number of fires, but fires at the end of the dry period (October) contributes more than 39\% of the total fire number. More than $88 \%$ of fires occurred in the dry period, strongly suggesting a coupling of the dry period and fire occurrences in the MRP area.

Fig. 8 shows that the fire season in MRP area started from the end of July when fires occur intensively with more than 4 fires/day in average. The peak of the fire season tends to start from the middle of August and ends at the start of November when large fires occur intensively with more than 26 fires/day in average. Fires in the peak fire period were 2938 or around $87.1 \%$ of the annual number of fires in the MRP area. Thus, based on the data here we suggest the middle of August as both the peak of the dry period and the start of the peak of the fire season.

Fig. 9 shows that the peat fire occurrences in the MRP area coincide with the precipitation curve. Daily precipitation decreased gradually from June and reached the lowest point in the middle of August, creating the necessary dry conditions for fires to ignite. Then, fires start to occur on a daily basis from the middle of June and become numerous from the end of July, making the end 


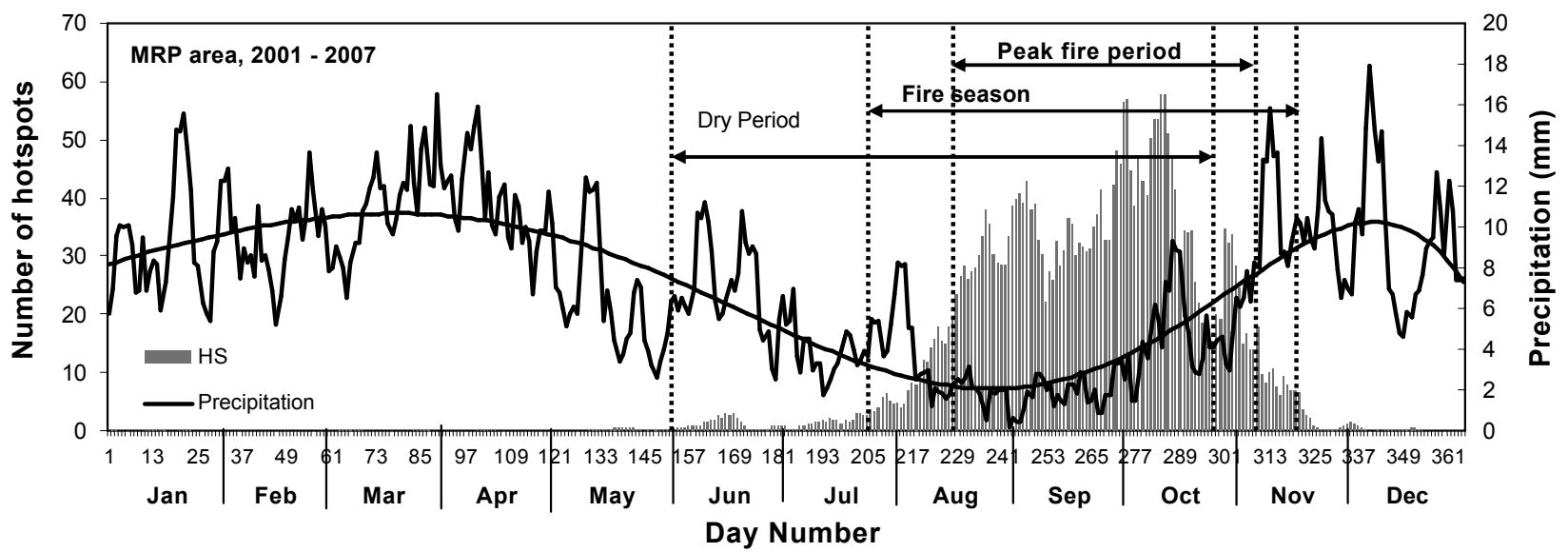

Fig. 9. Daily precipitation and hotspot occurrences in the MRP area. The smoothed-thick curve represents the daily precipitation observational mean.
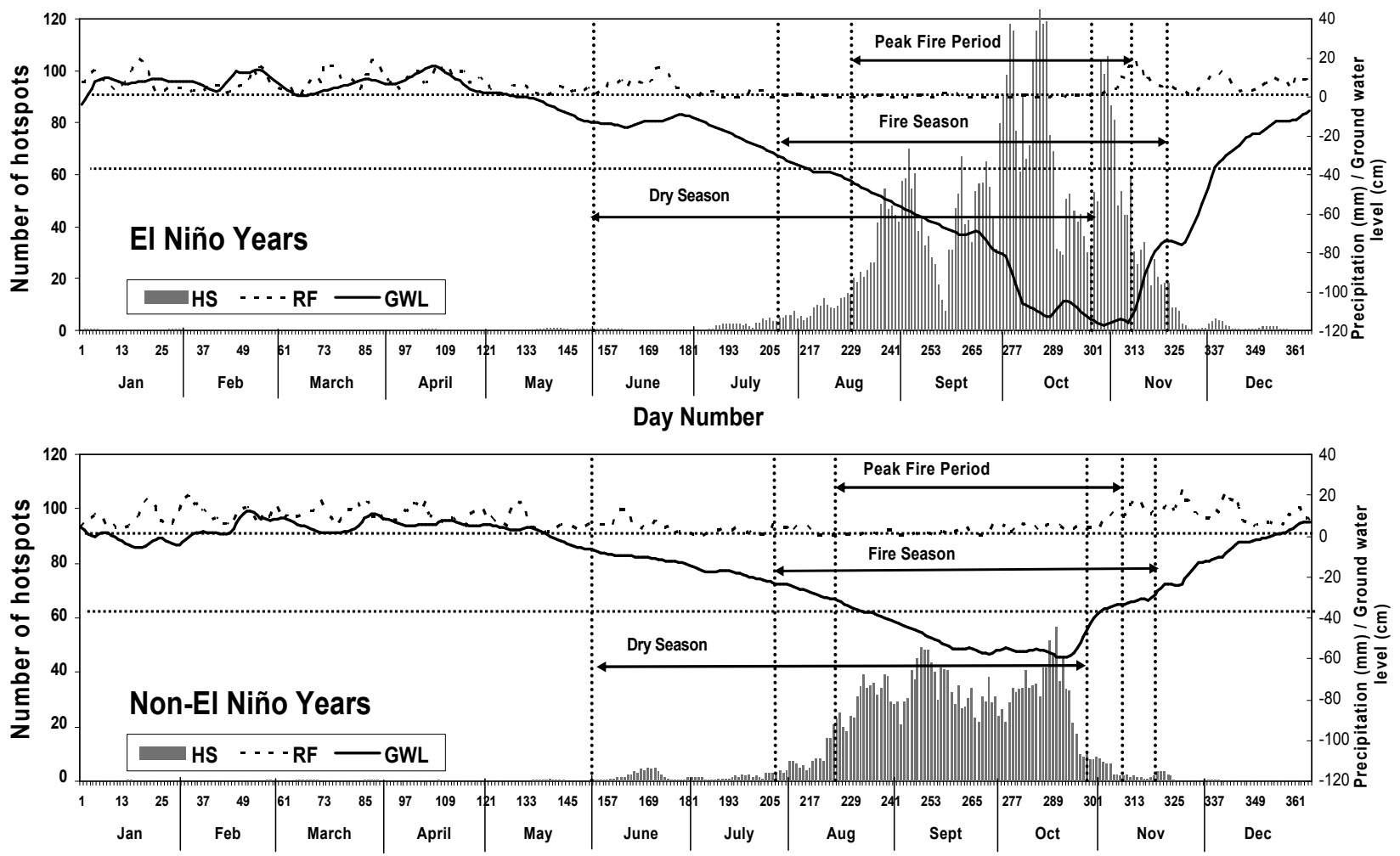

Day Number

Fig. 10. Average seasonal cycle of precipitation, GWL and peat fire occurrences in MRP area in El Nino years and Non-El Niño years.

of July the start of the fire season in the MRP area. The fire period peaks from the middle of August when daily precipitation drops below the lowest mean value, less than $3 \mathrm{~mm}$. This is caused as fires spread rapidly when they take hold in dry surface biomass and dry peat (Frandsen 1997).

The fire season ended at the start of November or about ten days after the end of the dry season at the end of October. This may indicate that peat in the MRP area is still in the dry condition at the beginning of the wet period, after suffering from the severe dry conditions of the long dry period, thus maintaining conditions where ignition may easily occur.

The above conditions of the peat fire season in the $\mathrm{MRP}$ area are present in both in El Niño years and non-El Niño years (Fig. 10). Fires occurs following precipitation 
patterns with little or no rainfall during the dry period. Fires are fewer and the period of occurrence is shorter in non-El Niño years, but both El Niño and non-El Niño years show the same starting day of the fire season (DN 212, end of July) and peak fire period (DN 230, middle of August). The fire season is shorter in non-El Niño years (DN 296, end of October) than in El Niño years (DN 316, start of November). Large amounts of precipitation at the end of the dry period significantly decreases the number of fires, followed by the end of peak fire period and fire season in non-El Niño years at DN 295 and DN 306, respectively. However, the peak fire period and fire season in El Niño years lasts longer (DN 316 and DN 323, respectively); this may be a result of the still dry condition of the peat early in November due to low rainfall pattern at the beginning of rainy season in El Niño years. The composite seasonal precipitation and fire cycle in Fig. 10 is derived from years 2002 and 2006 for the El Niño years, and years 2001, 2003, 2004 and 2005 for the non-El Niño years.

\section{Ground water levels, precipitation, and peat fire occurrence}

The ground water level (GWL) could be one of the key indicators determining fire activity in peatlands because the dryness of peat and the moisture content of grass, litter, and the surface peat are directly influenced by the GWL (Usup et al. 2004). Figs. 10 and 11 shows that peat fires occurred when the GWL was lower than the soil surface both in El Niño years and non-El Niño years; suggesting that the low GWL accelerated conditions where fires ignite with ease.

Figs. 10 and 11 show that fire occurrences in the MRP area coincide with the GWL. The decrease in GWL in El Niño years is faster than in non-El Niño years (Fig 10). The GWL dropped below the soil surface from the middle of May and reached a minimum of $-117.4 \mathrm{~cm}$ at the end of October in El Niño years; in non- El Niño years the minimum in GWL was -59.5 , reached at the middle of October. This evidence strongly indicates that the dry conditions of the peat in El Niño years during the dry period is more severe rather than that in the non-El Niño years, thus accelerating and causing larger numbers of fires in El Niño years than in non-El Niño years.

The fire records both in El Niño years and non-El Niño years (Figs 10 and 11) showed that the fire season in the MRP area started when the GWL dropped to around $-30 \mathrm{~cm}$ and fires become more severe when the GWL is below $-40 \mathrm{~cm}$. The moisture content of the top layer of the peat will decrease when the ground water level in tropical peat drops below $-40 \mathrm{~cm}$ (from the surface level) (Wösten et al. 2008), making the peat susceptible to fires. There is an exception in 2004 where large numbers of fires start when the GWL is at around $-20 \mathrm{~cm}$ (Fig. 11), but in this year the GWL progressively decreased until it reached -71.4 at the middle of October (not showed in Fig. 11) and most of the fires occurred when the GWL was below $-40 \mathrm{~cm}$. Therefore this study suggests $-40 \mathrm{~cm}$ as a critical level of GWL for large peat fire occurrences

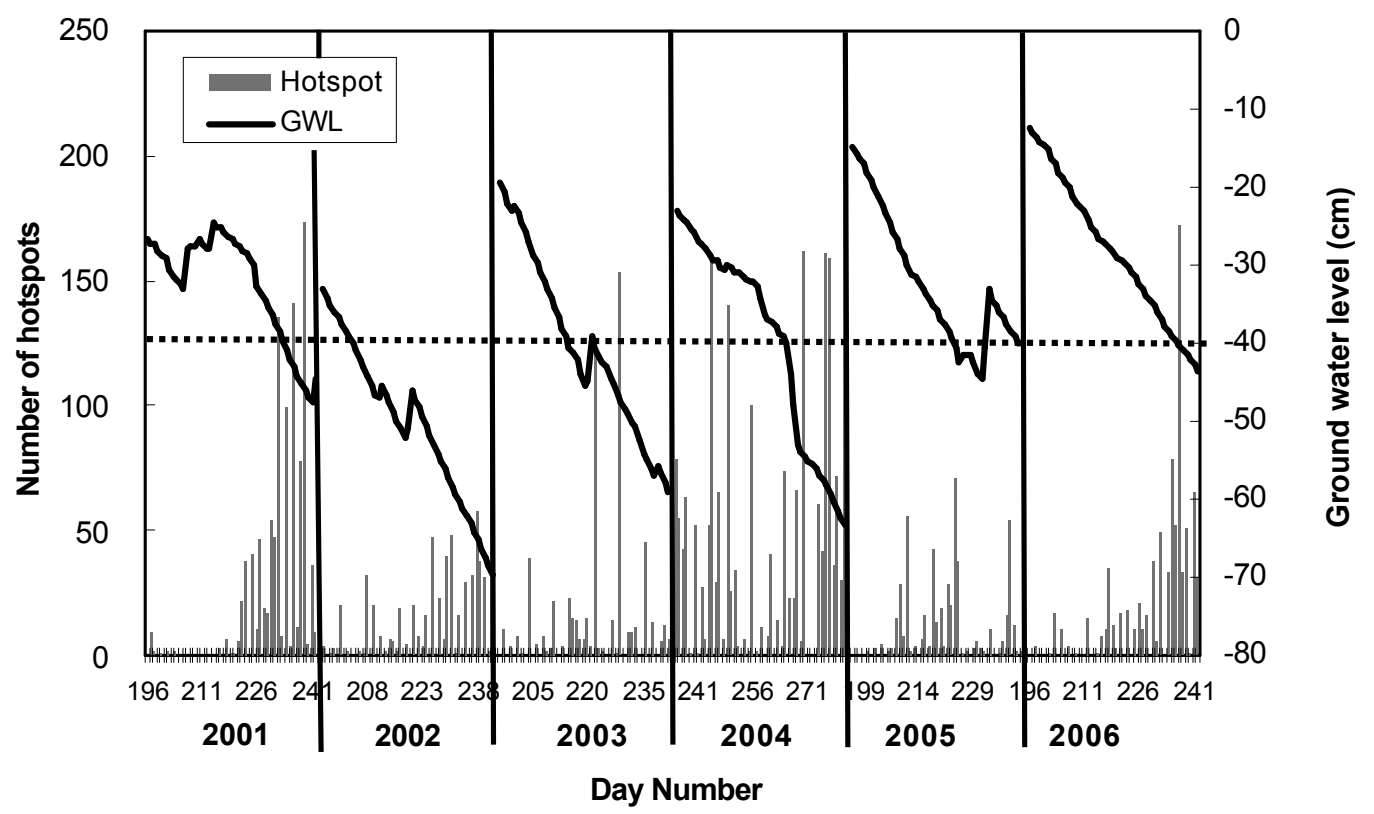

Fig. 11. Ground water level and peat fire occurrences, middle of July - middle of August, 2001 - 2006. 


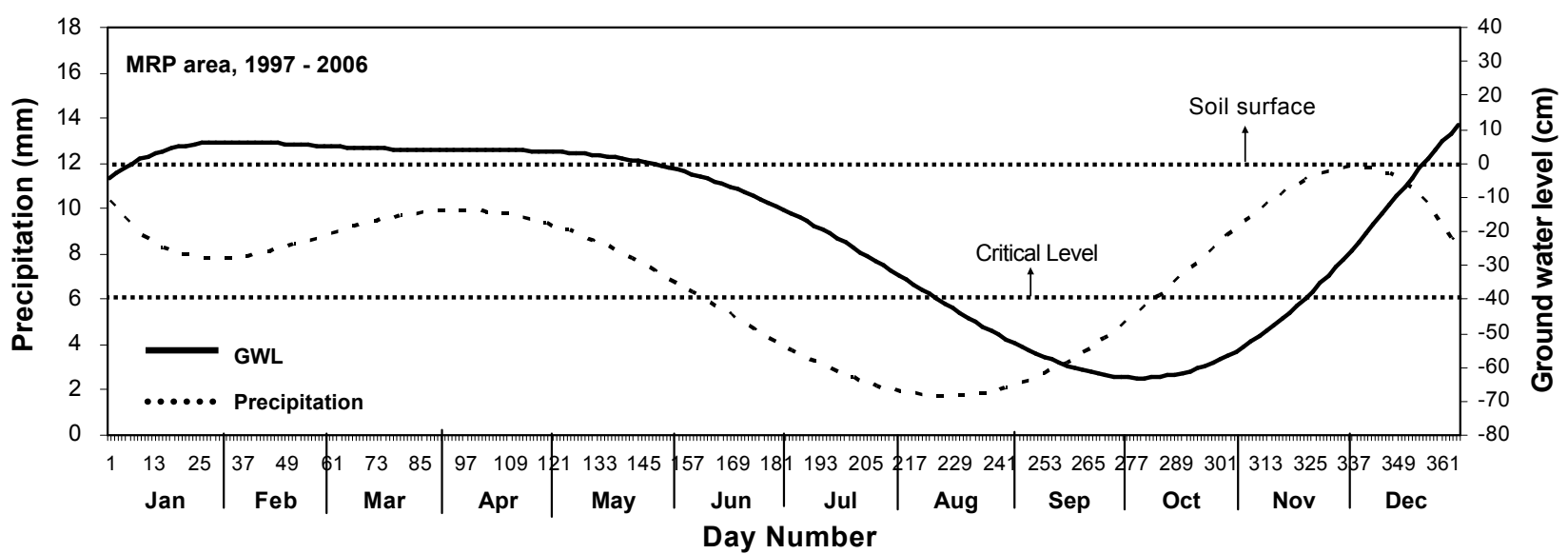

Fig. 12. Ground water level and precipitation changes. The smoothed-solid thick curve represents the daily GWL observational mean and the smoothed-dashed curve represents the daily precipitation observational mean.

in the MRP area, and this GWL could be used as an indicator suggesting a high likelihood of severe fire occurrences in the MRP area.

Fig. 12 shows that the GWL reached $-40 \mathrm{~cm}$ at the middle of August when the peak fire period has started, and indicates $-40 \mathrm{~cm}$ as a critical value of GWL for large peat fire occurrences. Fig. 12 also shows the changes in GWL in the MRP area. The GWL stays steady at around 5 $\mathrm{cm}$ above the soil surface between January and the middle of May, in the wet season; this suggests that the area could be categorized as a peat swamp forest area. The GWL decreased progressively below the soil surface during the dry period from the end of May until it reached the lowest value in early October; clearly indicating that the GWL followed the precipitation changes. However, there is a time-lag between GWL and precipitation.

There is about a one and a half month time-lag between the lowest precipitation in mid August and the lowest GWL in early October. The decrease in precipitation occurs over three months to reach the lowest in mid August (from mid May), but the lowering of GWL below the soil surface takes around 4.5 months from the middle of May until it reaches its lowest value in early October. The GWL then reaches the soil surface again at the end of December after the precipitation has reached its highest value in mid December. This may suggest that the recovery of the ground water level in the MRP area occurs after having been replenished by the water supplied by the continuous precipitation.

Finally, this study has established the factors that are important for peat fire occurrences in the MRP area, including: the onset of the dry period and precipitation patterns, Niño 3.4 SST Anomalies, and ground water level changes in the dry season. As peat fires in the MRP area are human caused fires (Putra et al. 2008), fire forecasts based on such information will assist in preventing devastating peat fire occurrences in the future in the MRP area.

\section{CONCLUSIONS}

The analysis using daily precipitation data, hotspot data, Niño 3.4 SST Anomalies, and ground water levels clearly support the following conclusions:

1. The 30 year daily precipitation data analysis showed large differences in the precipitation pattern of the dry and wet periods in Palangkaraya where the mean daily precipitation in the dry period $(4.7 \mathrm{~mm})$ is less than half of that in the wet period $(10 \mathrm{~mm})$. Less than $3 \mathrm{~mm}$ of daily precipitation and a higher than $80 \%$ incidence of rainless days in the middle of August suggests the middle of August as the peak of the dry period as well as the start of the peak fire period. Under this precipitation pattern, the dryness of the peat is increased and stimulated the large number of fire occurrences. Around 2938 of fires or $87.1 \%$ of the annual number of fires in the MRP area occurred in the peak fire period, indicating that the large areas of bare peat in the MRP area now are highly susceptibility to fires, coupled with the precipitation pattern of the dry period.

2. There is a negative correlation between Niño 3.4 SST Anomalies and precipitation; and a high positive correlation between Niño 3.4 SST Anomalies, severity 
of dry period and number of fie occurrences strongly indicate a coupling of precipitation, Niño 3.4 SST Anomalies, and peat fire occurrences.

3. The low precipitation pattern of the dry period decreased GWL below the soil surface and the fire season occurred under negative GWL conditions (ground water level below the soil surface); clearly showing that fire occurrences are closely related to ground water level changes and precipitation variability in the dry period.

4. The peak of the fire season coincided with a low GWL of less than $-40 \mathrm{~cm}$, and suggests $-40 \mathrm{~cm}$ as a critical level for peat fire occurrences. Thus, $-40 \mathrm{~cm}$ of GWL should be used as one indicator of the likelihood of severe fire occurrences in the MRP area.

ACKNOWLEDGMENTS The authors very grateful to Dr. Hidenori Takahashi, Hokkaido Institute for Hydroclimate for providing the groundwater level data and the information on its measurement and to Dr. Minnie Wong, University of Maryland, Fire Information for Resource Management System (FIRMS), USA for providing the MODIS fire datasets.

\section{REFERENCES}

Adinugroho WC, Suryadiputra NN, Saharjo BH, Siboro L. 2005. Manual of the Control of Fire in Peatlands and Peatland Forest. Wetlands International - Indonesia Programme and Wildlife Habitat Canada. Bogor.

Aldrian E, Susanto RD. 2003. Identification of three dominant rainfall regions within Indonesia and their relationship to sea surface temperature. International Journal of Climatology 23: 1435-1452.

Dennis R. 1999. A Review of Fire Projects in Indonesia (1982-1998). CIFOR. Jakarta

Flannigan MD, Harrington JB. 1988. A study of the relation of meteorological variables to monthly provincial area burned by wildfire in Canada (1953 80). Journal of Applied Meteorology 27: 441-452.

Frandsen WH. 1997. Ignition probability of organic soils. Canadian Journal of Forest Research 27: 1471-1477.

Frederic A, Eva HD, Stibig H, Mayaux P, Gallego J, Richards T, Malingreau J. 2002. Determination of deforestation rates of the world's humid tropical forests. Science 297, 999: 999-1002.

Goldammer J, Seibert B. 1989. Natural rain forest fires in eastern Borneo during the Pleistocene and Holocene. Naturwissenschaften 76: 518-520.
Holden ZA, Morgan P, Crimmins MA, Steinhorst RK, Smith AMS. 2007. Fire season precipitation variability influences fire extent and severity in a large southwestern wilderness area, United States. Geophysical Research Letters, Vol. 34, L16708, 2007.

Hooijer A, Silvius M, Wosten H, Page S. 2006. Peat-CO2: Assessment of $\mathrm{CO}_{2}$ emission from drained peatlands in SE Asia. Delft Hydraulics Report Q3943 (2006).

MacKinnon K, Hatta G, Mangalik A. 1997. The Ecology of Kalimantan. Oxford University Press.

Ministry of Forestry. 2008. Forestry Statistics of Indonesia 2007.

Hayasaka, H. 2007. Recent large-scale fires in boreal and tropical forests. Journal of Disaster Research 2: 265275.

Murdiyarso D, Adiningsih E. 2006. Climate anomalies, Indonesian vegetation fires and terrestrial carbon emissions. Mitig Adapt Strat Glob Change, 101-112.

NASA/University of Maryland, 2002. MODIS Hotspot / Active Fire Detections. Data set. MODIS Rapid Response Project, NASA/GSFC [producer], University of Maryland, Fire Information for Resource Management System [distributors]. Available on-line [http://maps.geog.umd.edu]

Notohadiprawiro T. 1998. Mega-project of Central Kalimantan wetland development for food crop production, belief and truth. Proceedings of the International Peat Symposium the Spirit of Peatlands. Jyvaskyla, Finland, 7-9 Sept. 1998.

Putra EI, Hayasaka H, Takahashi H, Usup A. 2008. Recent peat fire activity in the Mega Rice Project area, Central Kalimantan, Indonesia. Journal of Disaster Research 3: 334-341

Putra EI, Hayasaka H. 2007. 2006 Severe Peat Fires in Indonesia. Proceeding of Japan Society for Natural Disaster Science Annual Symposium, Sapporo, 25-26 September 2007. 15-16.

Siegert F, Boehm H-DV, Rieley JO, Page SE, Jauhiainen J, Vasander H, Jaya A. 2001. Peat fires in Central Kalimantan, Indonesia: fire impacts and carbon release. International Symposium on Tropical Peatland, Jakarta, Indonesia, 22-23 August 2001.

Takahashi H, Usup A, Hayasaka, H, Limin SH. 2007. Overview of hydrological aspects for recent 10 years in the basins of River Sebangau and Kahayan. Environmental Conservation and Land Use Management of Wetland Ecosystem in Southeast Asia. Annual Report for April 2006 - March 2007.

Trenberth KE. 1997. The definition of El Niño. Bulletin of the American Meteorological Society 78: 2771-2777 
Usup A, Hashimoto Y, Takahashi H, Hayasaka H. 2004. Combustion and thermal characteristics of peat fire in tropical peatland in Central Kalimantan, Indonesia. Tropics 14: 1-19.

Wosten JHM, Clymans E, Page SE, Rieley JO, Limin SH. 2008. Peat-water interrelationship in a tropical peatland ecosystem in Southeast Asia. Catena 73: 212-224.

Received $26^{\text {th }}$ Oct. 2009

Accepted $28^{\text {th }}$ Apr. 2011 